\title{
Remagnetization of igneous rocks in Gupis area of Kohistan arc, northern Pakistan
}

\author{
Mirza Naseer Ahmad*, Yoshiki Fujiwara, and Lalu Prasad Paudel \\ Division of Earth and Planetary Sciences, Graduate School of Science, Hokkaido University, Sapporo 060-0810, Japan
}

(Received August 28, 2000; Revised February 2, 2001; Accepted February 6, 2001)

\begin{abstract}
The Kohistan arc was formed due to subduction of neo-Tethyan oceanic crust beneath Asia. The arc is comprised of volcanic, plutonic and sedimentary rocks of Mesozoic to Tertiary age, formed prior and after the suturing of the Indian and Asian continents. Paleomagnetic investigations have been carried out on Paleocene volcanic and plutonic rocks exposed in the northern part of the arc. A total of 110 samples from 16 sites were drilled. According to rock-magnetic studies the main magnetic carrier is magnetite. Optical microscopy study reveals that low-grade metamorphism have effected all rocks. Magnetite is found as both a primary magmatic mineral and secondary alteration product in all samples. Samples of volcanics yield post tilting characteristic remanent magnetizations (ChRM). The in situ mean direction of the ChRMs of the intrusives is similar to the in situ mean direction of volcanics. The presence of secondary magnetite in plutons, the similarity of in situ mean ChRM of plutons with that of post-tilting ChRMs of similar age volcanics and dissimilarity of the mean ChRM of plutons from expected directions at the time of formation of plutons support a secondary origin for the ChRM of plutons. As the ChRM directions of the volcanics and intrusives are the same, it implies that both ChRMs were acquired during the same remagnetization event. Comparing the mean paleolatitude $\left(25 \pm 6^{\circ} \mathrm{N}\right)$ from Gupis area with those from Indian APWP and considering the fact that there was prevailing heating event in Lower Tertiary in the area, the acquisition age of this secondary remanent magnetization can be bracketed between 50 and $35 \mathrm{Ma}$.
\end{abstract}

\section{Introduction}

It is well known that the Himalayan mountain belt was formed by the collision of Indian continent with the Asia (or Eurasia). The northwestern part of the Himalayan collision belt consists of an island arc sequence, termed as the Kohistan island arc, captured between the two colliding continents (Tahirkheli et al., 1979). Only a few paleomagnetic data are available from the Kohistan arc (Zaman and Torii, 1999; Ahmad et al., 2000), mainly due to poor accessibility of the area. Therefore most of the Kohistan arc remained sparsely studied and little is known about the paleoposition and rock-magnetic properties of the rocks of the arc. This is the first paleomagnetic and rock-magnetic study of volcanic and plutonic rocks of northern part of the arc. In this paper, we describe results of rock-magnetic and paleomagnetic analyses of the Paleocene volcanic and plutonic rocks exposed in the northern part of the arc. The main emphasis of this study is to investigate magnetic mineralogy, origin of natural remanent magnetization (NRM) and age of NRM of the volcanic and plutonic rocks of the area.

\section{Geology}

Kohistan is considered to be the crust of island arc which developed as a result of northward subduction of neo-Tethyan oceanic crust beneath Asia during the Jurassic and the Early

*Present address: Geoscience Laboratory, Geological Survey of Pakistan, Shahzad Town, Islamabad, Pakistan.

Copy right (C) The Society of Geomagnetism and Earth, Planetary and Space Sciences (SGEPSS); The Seismological Society of Japan; The Volcanological Society of Japan; The Geodetic Society of Japan; The Japanese Society for Planetary Sciences.
Cretaceous times (Tahirkheli et al., 1979). It has been inferred that the Kohistan arc originated as an intra-oceanic arc because of its mafic bulk composition, presence of marine sediments and pillow lavas (Khan et al., 1997; Searle et al., 1999). Isotopic data demonstrate the involvement of an enriched DUPAL-type mantle, suggesting that the Kohistan arc formed at or south of the present equator (Khan et al., 1997). This intra-oceanic phase of the arc (102-85 $\mathrm{Ma}$ ) ended when the arc collided with Asia along the Northern Suture (Fig. 1) (Petterson and Windley, 1985; Treloar et al., 1996). After this collision the arc remained as Andean type margin until its collision with the Indian continent in the Eocene along the Main Mantle Thrust (age of collision from Coward et al., 1987). The arc was upturned along Main Mantle Thrust (MMT) exposing deeper crustal levels in the southern part, whereas higher level seafloor sediments and volcanics are exposed in the northern part. The arc can be broadly divided into six components on the basis of structure and lithology (Treloar et al., 1989; Searle, 1991). They are: 1) high pressure garnet granulites and ultramafics of the Jijal Complex, 2) highly deformed amphibolite facies rocks of the Kamila Amphibolite belt, 3) mafic ultramafic stratiform plutonic complex termed as Chilas Complex, 4) the Chalt Volcanic Group consisting of metasediments and volcanics of greenschist and epidote-amphibolite facies, 5) the Yasin Group comprising of turbiditic slates, limestones and volcanoclastics and 6) the Kohistan batholith and related volcanic rocks forming the roof zone of the arc (Fig. 1).

In the northern part of the arc, which is the main focus of the present study, various types of volcanic and plutonic rocks are exposed. Treloar et al. (1996) described two ma- 


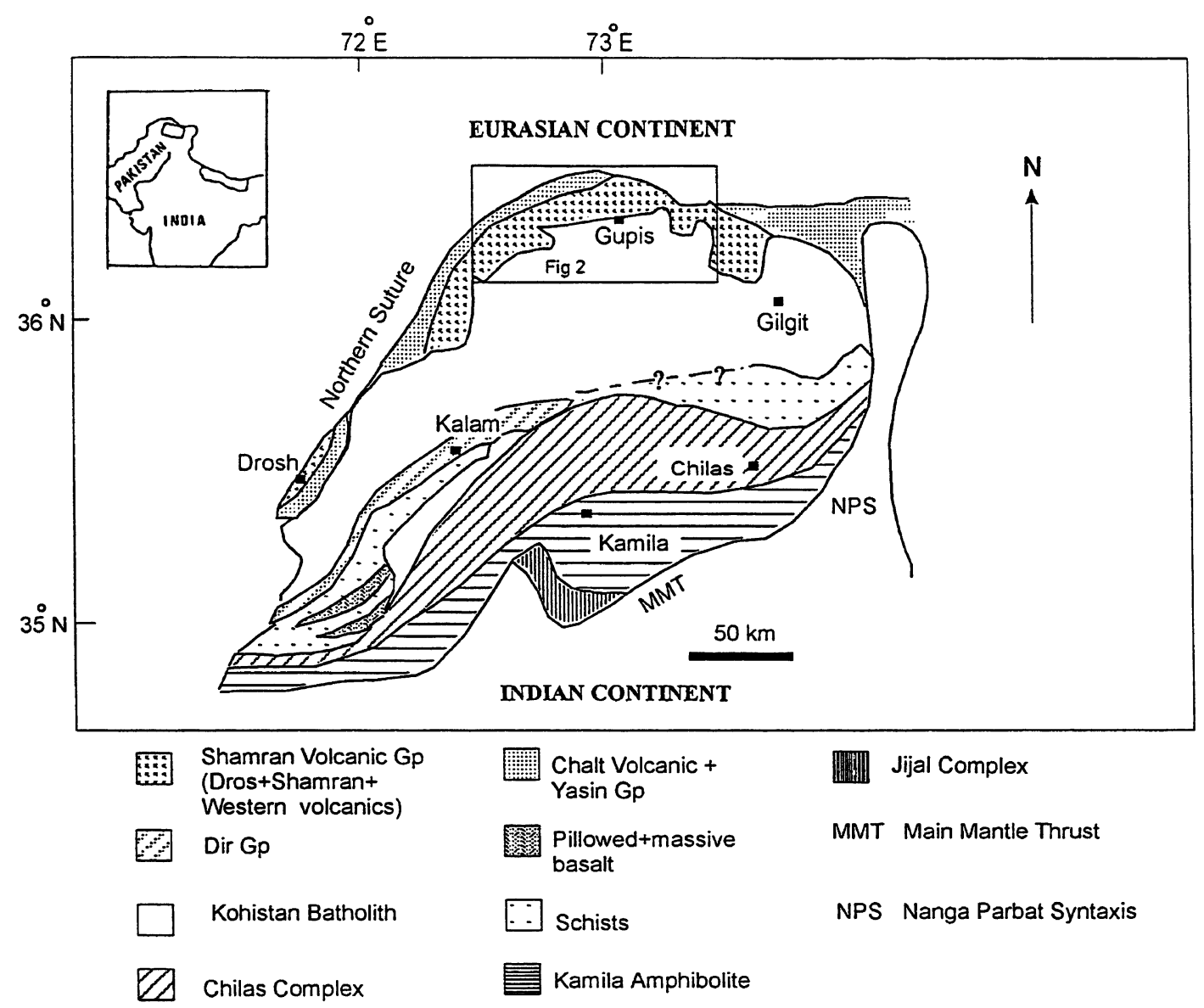

Fig. 1. Geological map of Kohistan island arc (after Treloar et al., 1996). ? is marked on the boundary where demarcation of geological units is not known exactly. The area east of NPS is termed as Ladakh arc.

jor types of volcanics exposed in the northern part of the arc: 1) the Cretaceous Chalt Volcanic Group comprised of deformed pillow lavas of island arc basement which are exposed in Hunza and nearby valleys (Fig. 1) and 2) the Shamran Volcanic Group and Western volcanics exposed west of Gilgit (Figs. 1, 2). According to Sullivan et al. (1993) the Western volcanic rocks display petrographic and geochemical characterstics similar to the Shamran volcanics. Further, they interpreted that the Shamran volcanics and the Western volcanics are continental marginal cover of the Kohistan arc rather than part of the island arc basement. The ${ }^{40} \mathrm{Ar}-$ ${ }^{39}$ Ar hornblende radiometric age of the Shamran volcanics is 58 $\pm 1 \mathrm{Ma}$ (Treloar et al., 1989; Sullivan et al., 1993). Pudsey (1986) mentioned a third type of volcanics, which are part of Aptian/Albian Yasin Group, overlying a one-meter thick sedimentary sequence. The thickness of these volcanics is about $2 \mathrm{~km}$.

Three main stages of magmatism can be distinguished in the Kohistan batholith. The first stage of plutonism is represented by a bimodal series of high-K and low-K high-SiO2 plutons (Searle, 1991), yielding a $\mathrm{Rb}-\mathrm{Sr}$ whole rock age of $102 \pm 2 \mathrm{Ma}$ (Petterson and Windley, 1985). These plutons have been deformed, probably during the collision of the Kohistan arc with Asian continental margin along Northern Suture (NS). The second stage plutons are undeformed and cut the deformed features of the first stage plutons and show a progressive increase in acidity from early gabbros through late granites. A number of these second stage granitoid plutons intruded west of Gilgit, in the Gupis, Yasin and Pingal areas. These are main target of our study. K-Ar hornblende ages of these plutons range from 61 to $53 \mathrm{Ma}$ and biotite ages from 62 to $40 \mathrm{Ma}$ (Treloar et al., 1989). On the basis of ${ }^{40} \mathrm{Ar} /{ }^{39} \mathrm{Ar}$ hornblende ages of $61 \mathrm{Ma}$ from Gupis pluton and $\mathrm{Rb}-\mathrm{Sr}$ age of $59 \mathrm{Ma}$ from nearby Gindai pluton, it has been inferred that these ages (K-Ar hornblende ages of 61-53 Ma) may be regarded as possible intrusion ages of plutons west of Gilgit without the effect of any resetting (Searle, 1991). The first and second stage of plutons were intruded by later stage apilitic pegmatic sheets, which are only exposed near Gilgit, east of the study area.

\section{Field and Laboratory Procedures}

Sampling was carried out by using a portable drill and orientations of cores were measured with a magnetic compass. At least seven samples were collected from each site. In total 110 samples were taken from 16 sites of Shamran volcanics ( 7 sites), Western volcanics (1 site), upper volcanics of Yasin Group (1 site) and second stage plutons of the Kohistan batholith (7 sites).

The volcanic sequence is comprised of amygdaloidal porphyritic andesitic lavas. There are also intermediate to acidic lavas and finely bedded tuffs with intercalated shaly sedi- 


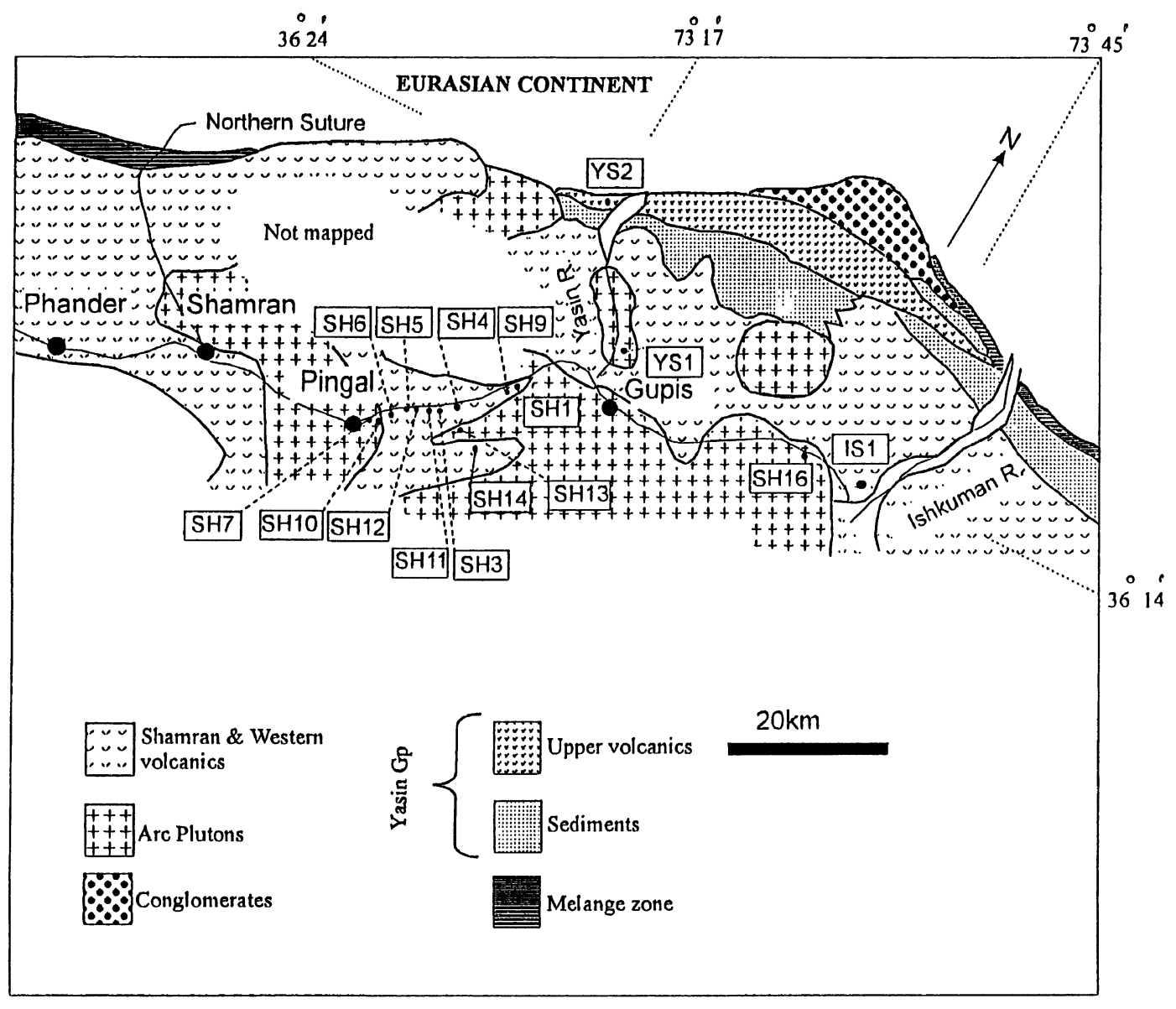

Fig. 2. Location of sampling sites. Lithologies are marked after (Pudsey et al., 1985). Site SH4 is comprised of granitic samples from small granitic body not shown on the map. Site SH9G is also not shown on the map it is close to site SH9 and consists of granitic samples from small granitic body near site SH9.

ments. Locally pillow structure is also preserved. As the cavities filled from the bottom up, partially filled amygdules provide an indicator of stratigraphic up direction (Twiss and Moores, 1992). Strike and dip orientations of the intercalated sediments are also used for structure correction of paleomagnetic data of volcanics. Locally preserved pillow lava structure is also useful to know stratigraphic up direction. In the case of plutons, bedding-tilt correction is applied to ChRMs by using bedding-tilt data of nearby volcanic exposures. The age of the volcanics and plutons is almost the same. The tilting of volcanics and plutons may have been occurred at the same time, during some tectonic event.

Paleomagnetic measurements were made at Hokkaido University, Sapporo, Japan, using a SSM-1A spinner magnetometer. Samples were thermally demagnetized in 13 steps up to $580^{\circ} \mathrm{C}$. NRM components were analysed using principle component analysis (Kirschvink, 1980). $k$ and $\alpha-95$ for mean directions were calculated by using Fisher statistics (Fisher, 1953).

The magnetic mineralogy was studied with various conventional techniques such as isothermal remanent magnetization (IRM) acquisition up to the maximum available field of $400 \mathrm{mT}$, and backfield and stepwise thermal demagnetization of IRMs. Low-temperature magnetometry was also studied for selected samples at low temperature laboratory of
Division of Physics, Hokkaido University, Sapporo, Japan. For this purpose saturation IRM (SIRM) was imparted at $5 \mathrm{~K}$, using a field of $5 \mathrm{~T}$ and the sample was continuously heated up to $300 \mathrm{~K}$, using a Quantum Design Magnetic Property Measurements System (MPMS). To investigate mineralogy of the rocks, microscopic observations were made both in transmitted and reflected lights for at least one representative sample per site.

\section{Results}

\subsection{IRM and low temperature analyses}

According to stepwise IRM acquisition and backfield demagnetization experiments, there is not much variation in the rock-magnetic characteristics of the volcanics and the intrusives. Most of the samples of the volcanics show a sharp increase in IRM up to the application of $50 \mathrm{mT}$ followed by gradual increase till they attain saturation up to $150 \mathrm{mT}$. This SIRM has low coercivity and reduced to zero by the application of 25 to $35 \mathrm{mT}$ backfield (Fig. 3(a)). Samples of three sites indicate comparatively harder magnetic behavior as saturation is attained at about $300 \mathrm{mT}$ (Fig. 3(b)) and higher back field $(50 \mathrm{mT})$ is required to remove the SIRM. IRMs of intrusive rocks saturate at about $150 \mathrm{mT}$ and the SIRMs have low coercivity ranging from $20 \mathrm{mT}$ to $30 \mathrm{mT}$ (Fig. 3(c)). Stepwise thermal demagnetization of the SIRMs 


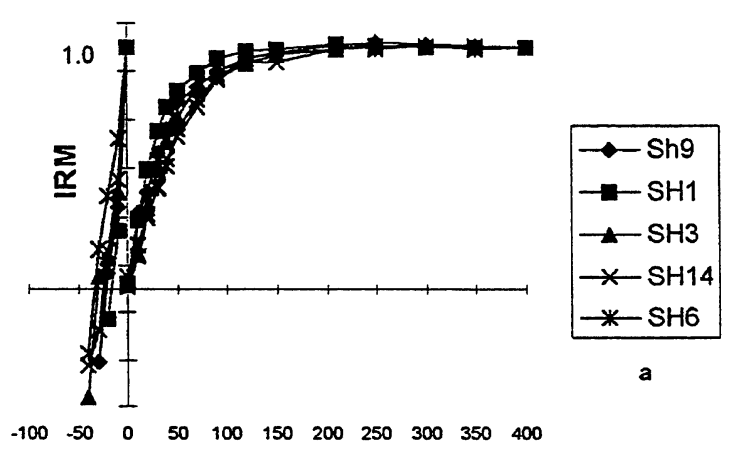

Applied Field (mT)

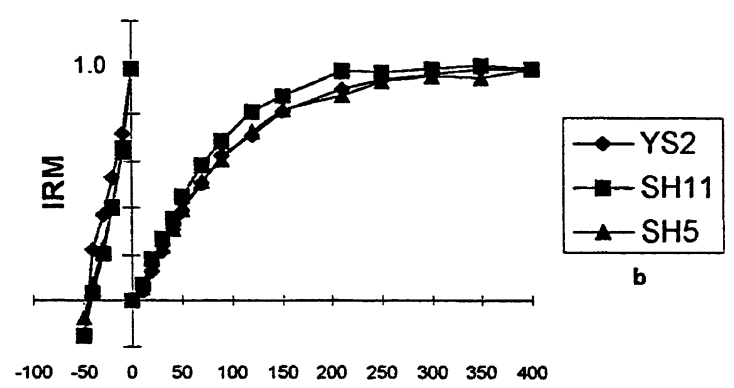

Applied Field (mT)

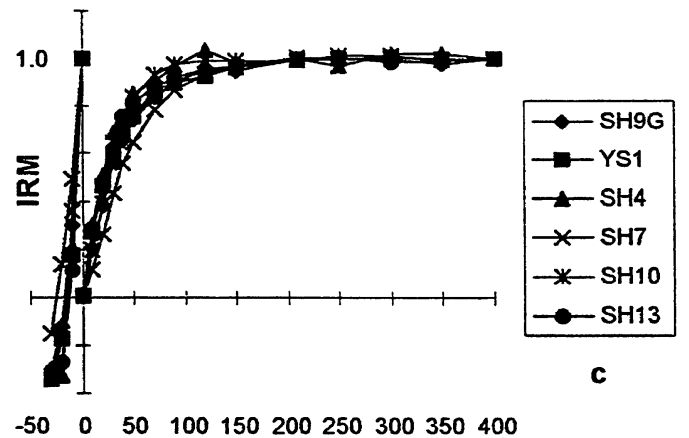

Applied Field (mT)

Fig. 3. Normalized curve for IRM experiment along with back field demagnetization a) samples of volcanics showing low coercivity b) volcanics having comparatively high coercivity c) intrusive rocks.

of both volcanic and plutonic rocks shows linear decrease up to $580^{\circ} \mathrm{C}$ (Fig. 4). SIRM warming curve (from $5 \mathrm{~K}$ to $300 \mathrm{~K}$ ) shows sharp drop in the intensity at about $110 \mathrm{~K}$ (Fig. 4(c)).

\subsection{Petrography}

About 20 rock samples were studied under the microscope both in transmitted and reflected lights. The observed rocks display wide mineralogical and textural variation. They can be classified into six main igneous rock types: diorite, andesite, granodiorite, granite, hornblendite and tuff. Slight deformation and low-grade metamorphism have affected all the rocks. The mafic minerals like pyroxene, hornblende and biotite have been partially or completely altered to chlorite, epidote, calcite and opaques. Plagioclase has been altered to kaolin and chlorite. Some mafic rocks have been changed
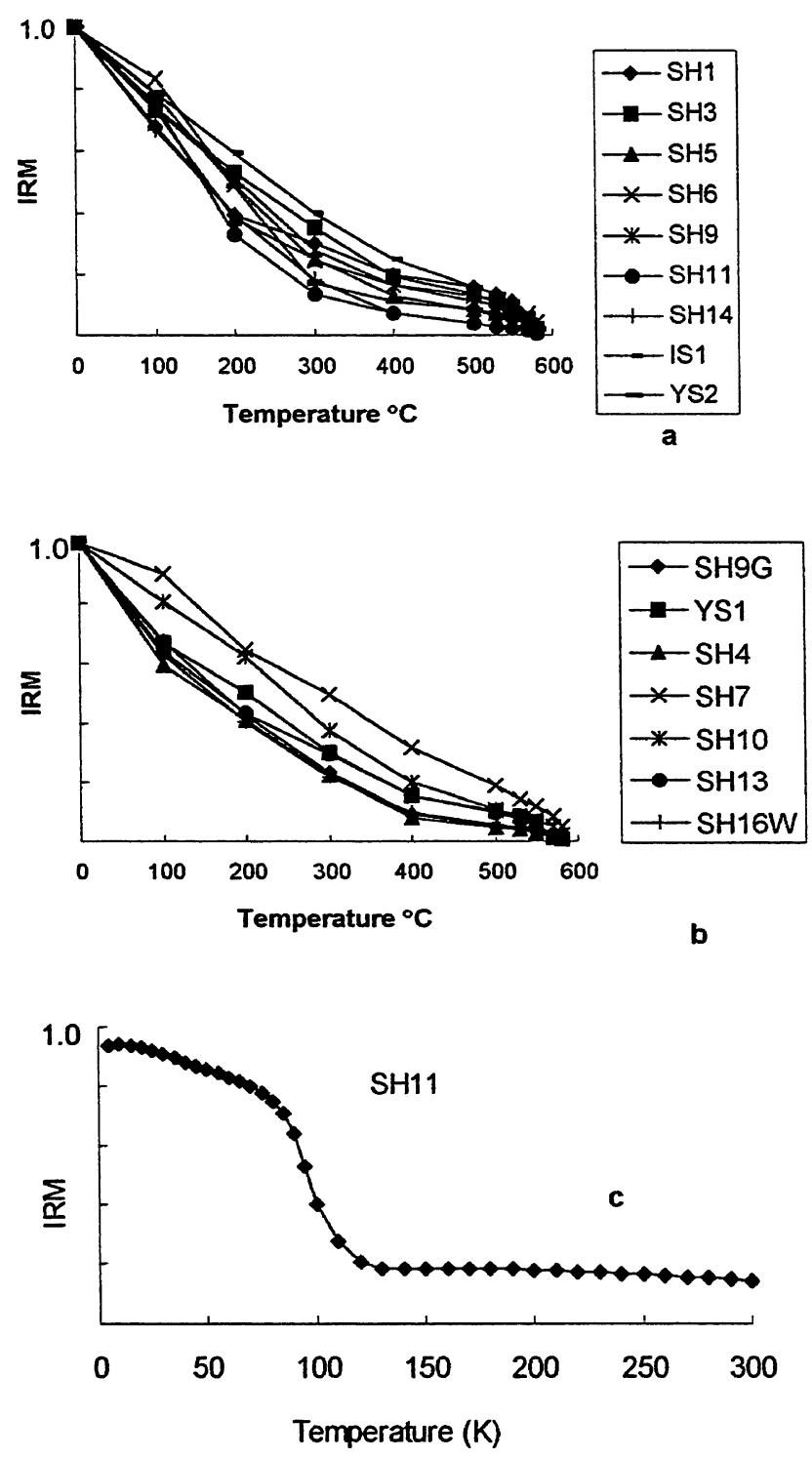

Fig. 4. Normalized curves of thermal demagnetization of isothermal magnetization of a) volcanics b) Intrusives. c) Normalized SIRM curve of sample of site SH11 during warming from $5 \mathrm{~K}$ to $300 \mathrm{~K}$.

to greenschists (SH1, SH3, SH9 and IS1). The presence of epidote in some samples indicates that the rocks have been heated at least up to $300^{\circ} \mathrm{C}$ (Muffler and White, 1969).

Opaque minerals occur as both primary magmatic products and secondary alteration products of mafic minerals in all of the samples (Fig. 5). They include mainly magnetite, ilmenite and pyrite. The primary magnetite and ilmenite is found as large (up to $0.5 \mathrm{~mm}$ ) irregular grains in the interstices of other minerals. Sometimes they occur as inclusions in hornblende and biotite. The primary magnetite grains show corroded boundaries and are sometimes altered to sphene $\left(\mathrm{CaTiO}_{5}\right)$. The sphene can be produced from early Ti-rich magnetites and this sphene replacement requires a minimum metamorphic temperature of about $250^{\circ} \mathrm{C}$ (Ade-Hall et al., 1971). Secondary magnetite, ilmenite and pyrite are the alteration products of pyroxene, hornblende and biotite. They are found only as inclusions in pseudomorphs of these minerals. 
a
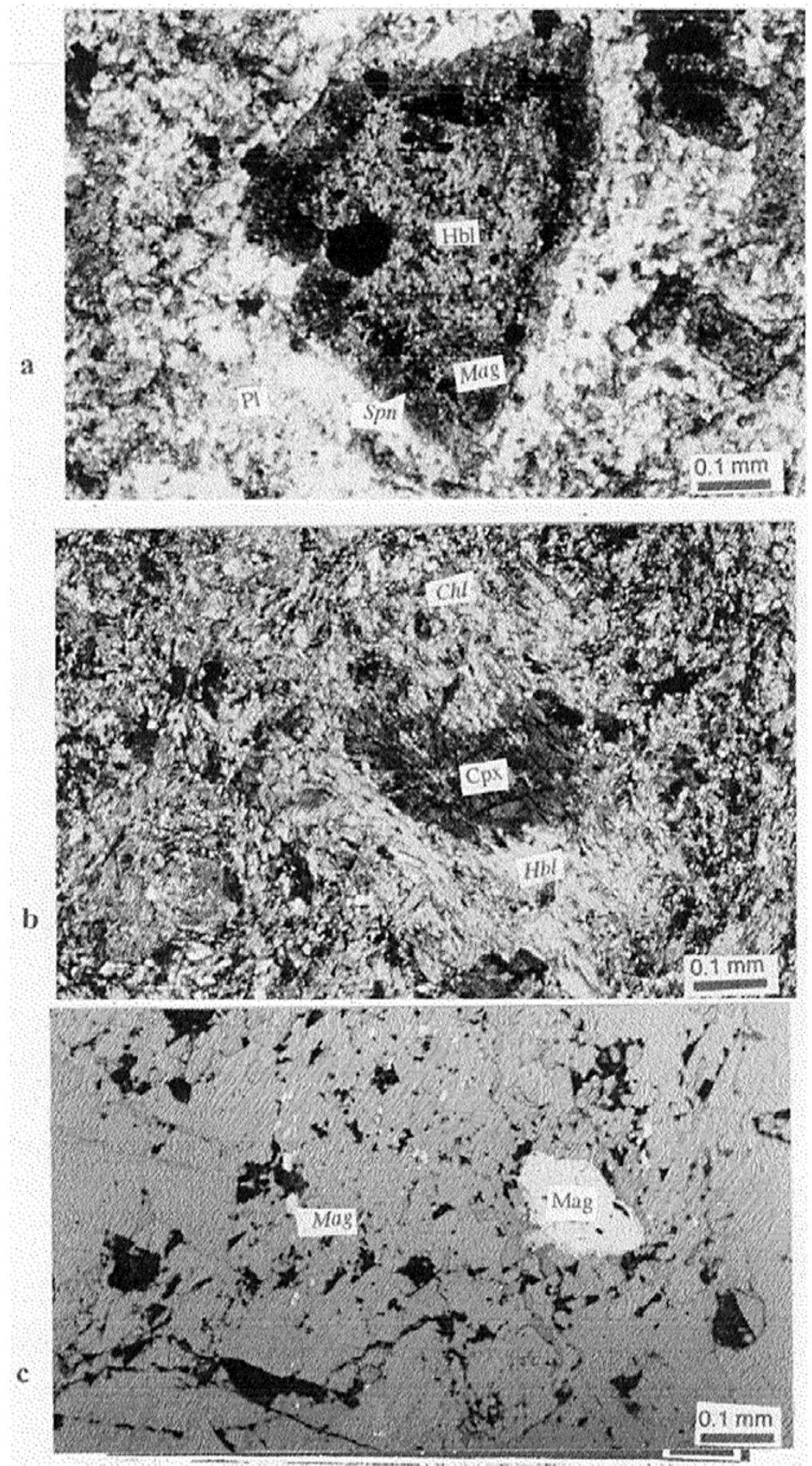

Fig. 5. Photomicrograph of a) Highly altered hornblende grain to magnetite and sphene in sample SH9. b) Sample IS1 has been changed to greenschist by alteration of clinopyroxene and hornblende to chlorite. c) Magnetite is distinguished under the reflected light in tuff (YS2). The primary magnetite are coarse grained and show corroded boundary while secondary magnetite are fine-grained. Note: Magmatic minerals are labeled with upright letters and the secondary minerals are labeled with italic letters.

\subsection{Paleomagnetic measurements}

4.3.1 Volcanics Thermal demagnetization of samples of volcanics shows two types of magnetic behavior: (a) samples from sites IS1, SH1, SH3 and SH9 show only minor reduction of $\mathrm{NRM}$ intensity up to $530^{\circ} \mathrm{C}$, and rapid decrease from 530 to $580^{\circ} \mathrm{C}$ (Fig. 6(a)), (b) Samples from sites YS2, SH5, SH6, SH11 and SH14 show gradual intensity decay up to $580^{\circ} \mathrm{C}$ and in most cases less than $30 \%$ of the initial intensity remained after $300^{\circ} \mathrm{C}$ (Fig. 6(b)). These two groups also show distinctive behaviour in terms of vector component plots (Zijderveld, 1967). Magnetization of samples of category (a) indicate the presence of predominantly single-component, having $570-580^{\circ} \mathrm{C}$ unblocking temperatures (Fig. 7(a)), whereas those of category (b) show charac- 

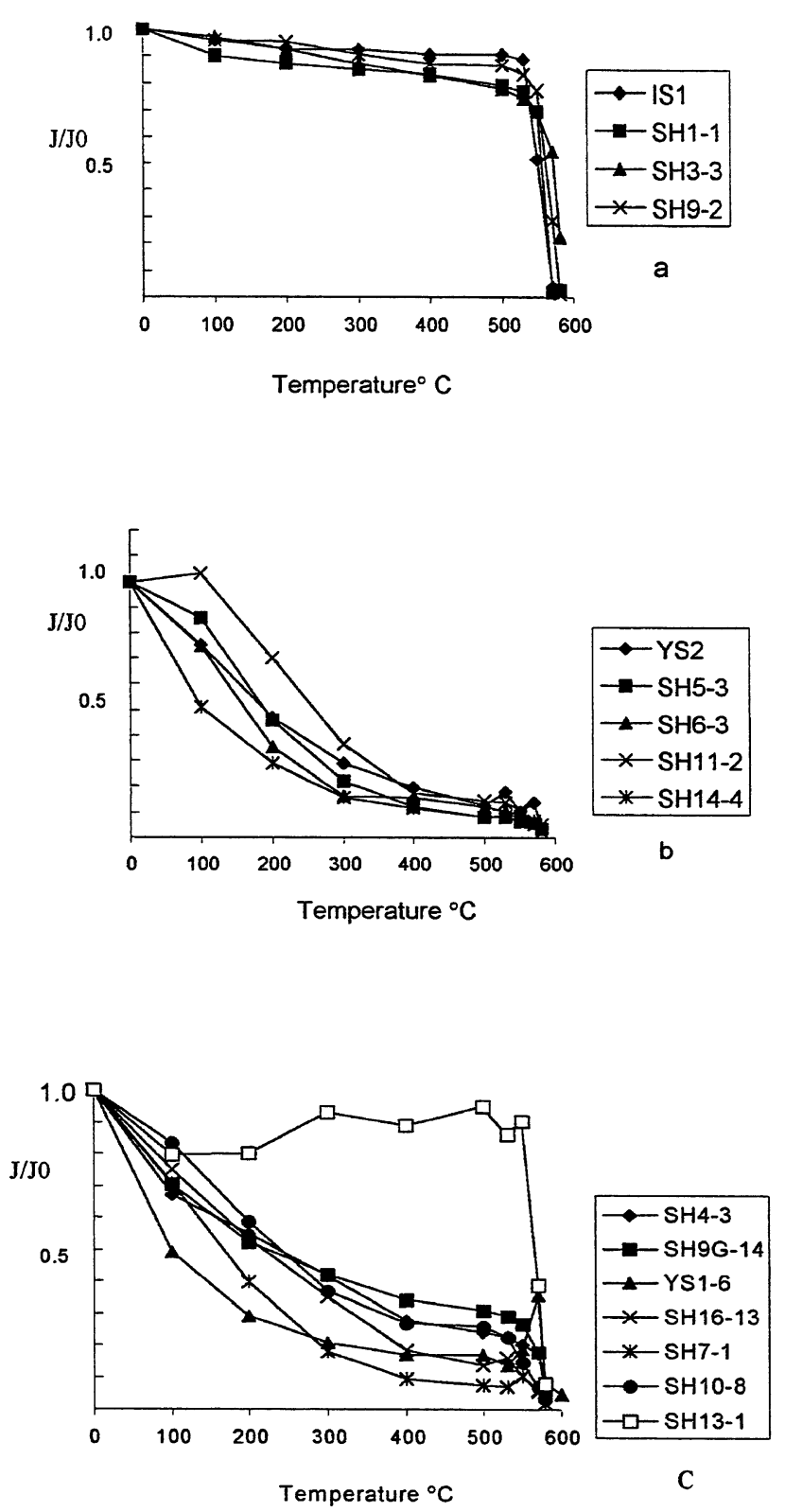

Fig. 6. Normalized intensity decay curves for a) volcanics showing minor reduction of NRM intensity up to unblocking temperature b) showing gradual intensity decay up to unblocking temperature c) for intrusives during thermal demagnetization.

teristic remanent magnetization (ChRM) components after removal of a rather soft component with intermediate unblocking temperatures of $400-500^{\circ} \mathrm{C}$ (Fig. 7(b)). This component gives magnetization direction parallel to the present Earth's magnetic field; thus it is interpreted to be of recent origin. The origin of this unusual high unblocking temperature of this component is unclear. This may not be TVRM, because there is no geological evidence of elevated temperatures in recent geological period. One possible explanation is high NRM intensities of low temperature viscous component as compared to high temperature component. This situation can arise due to the small amount of SD/PSD grains as compared to MD grains. In this case junction between low temperature and high temperature components will be pushed toward higher temperatures (Dunlop and Ozdemir,
1997; Zwing and Bachtadse, 2000). The ChRM component is represented by a linear segment directed towards the origin of the vector component plot. In geographic coordinates, samples of six sites reveal normal and those of one site show an antipodal reversed direction (Fig. 8(a)). Statistical parameters show that directions become scattered after the application of the bedding-tilt correction (Fig. 8(b); Table 1). The mean direction before structural correction is Dec $=341.6^{\circ}$, Inc $=45.6^{\circ}$ (Table 1$)$, which is calculated after converting the reversed direction to normal polarity. The mean direction of samples of site SH6 is discarded because its respective direction of magnetization is far away from the rest of data (Table 1). After tilt correction, site SH6 yield shallow inclination (4.9), which is consistent with the expected Paleocene (age of volcanics) direction of the area. The ChRM of samples of this site may represent primary magnetizations. Anyhow on the basis of data of one site, it is premature to conclude about the origin of ChRM. Additional data is needed from the west of the survey area in order to explore the possibility of primary ChRM. NRM intensities from samples of one site (YS2) were too low to yield significant results.

4.3.2 Intrusives Most of the intrusive rocks show gradual intensity decay up to $580^{\circ} \mathrm{C}$ (Fig. 6(c)) and two different remanent components are observed on the vector plot. First component, removed up to $400^{\circ} \mathrm{C}$ or in some cases up to $500^{\circ} \mathrm{C}$, is parallel to the present local geomagnetic field. Whereas the second one, which is ChRM component, is observed between 530 and $580^{\circ} \mathrm{C}$ (Fig. 7(d)). The mean direction of the ChRM $\left(\mathrm{Dec}=340^{\circ}\right.$, Inc $\left.=39.8^{\circ}\right)$ in geographic coordinates is similar to that of the volcanics (Table 1). Samples from two sites (SH16 and SH7) of intrusive rocks, show low intensity of NRM after heating over $300^{\circ} \mathrm{C}$ and give erratic directions. Hence no reliable ChRM component could be isolated for these two sites.

\section{Discussion}

\subsection{Magnetic mineralogy}

The low coercivity shown by complete saturation of the IRM at low fields (150-300 mT) and unblocking of NRM and SIRM at about $580^{\circ} \mathrm{C}$ is indicative of magnetite in these samples (Fig. 3; Fig. 4). In low temperature analysis curve (Fig. 4(c)), the IRM intensity drop is at about $110 \mathrm{~K}$. The Verwey transition (Verwey, 1939) in pure stoichiometric natural magnetite crystal is observed at $119 \mathrm{~K}$ (Ozdemir and Dunlop, 1999). Slight deviations from stoichiometry and the presence of impurities can suppress the transition (Ozdemir et al., 1993). The transition observed at $110 \mathrm{~K}$ may be because of above mentioned two reasons. Optical microscopic observations also suggest that the dominant magnetic mineral in the volcanics and the intrusives is magnetite.

\subsection{Origin and age of ChRM}

The ChRM directions of volcanics fail the fold test and they are clearly post tilting remanent magnetizations (Table 1). The ChRMs of intrusives have similar mean direction to that of volcanics (Table 1). There are two possibilities: either the volcanics were remagnetized at the time of intrusive activity or both have suffered some later remagnetization. For the former case ChRM of intrusives will be primary and for the latter case ChRM will be secondary. 


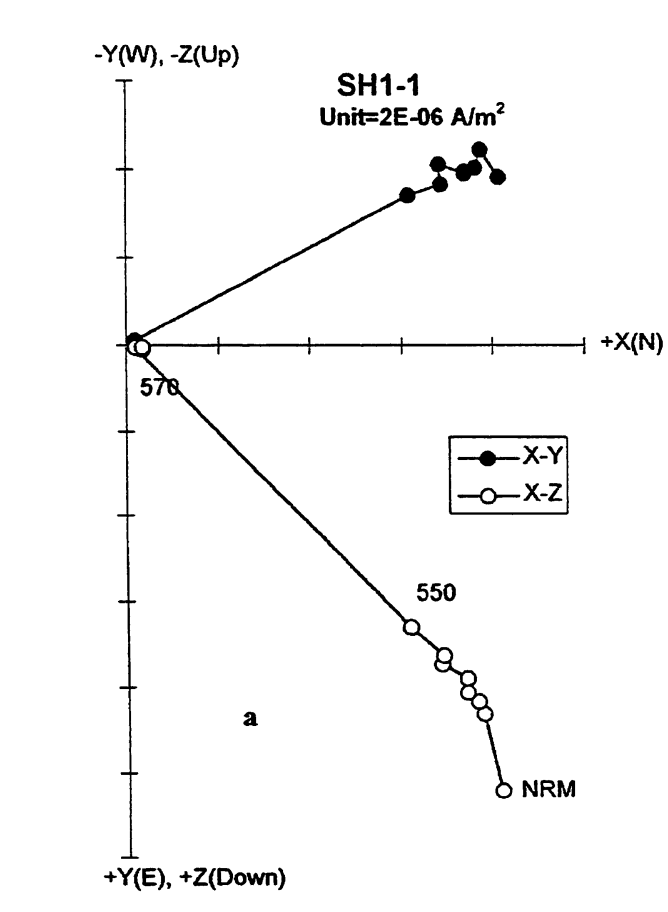

SH11-2

Unit=1E-06A $\mathrm{m}^{2}$
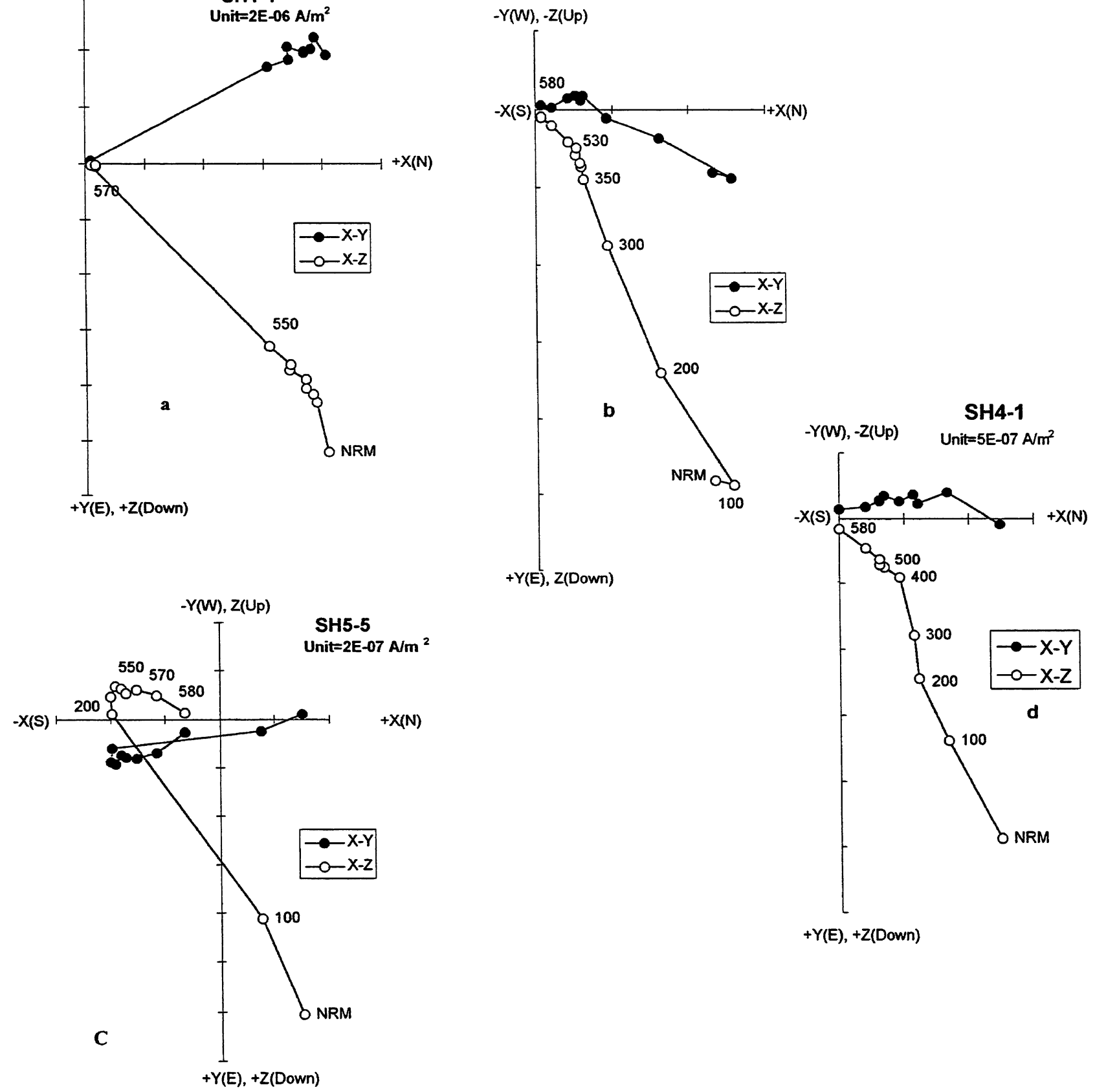

$+Y(E),+Z(D o w n)$

Fig. 7. Zijderveld diagram for a) volcanics showing only one component b) volcanics showing two components c) volcanics having ChRM with reverse polarity and d) intrusive rock. All projections are in Geographic coordinates.

The statistical parameters of the mean ChRM of intrusives before and after structure correction, however suggest that the ChRMs post tilting (Table 1). Only on the basis of structure correction this conclusion is somewhat premature because we did not note the exact paleohorizontal plane for intrusives. They have been corrected for structure correction by using strike and dip data of nearby volcanic exposures and question arises could the intrusives remained un-tilted and ChRMs are primary? This possibility can be disregarded on the basis of following points.

1) The mean ChRMs for intrusives yield paleolatitudes $\left(22.4^{\circ} \mathrm{N}\right)$ that are different from the expected paleolatitudes at the time of (Paleocene) intrusive activity $\left(0-10^{\circ} \mathrm{N}\right.$; Klootwijk, 1984).

2) The possibility that intrusives remained un-tilted is too remote because contemporary age volcanics in the area have suffered moderate to high angle tilting.

Moreover the presence of secondary magnetite also supports the secondary nature of the ChRMs of the intrusives. The metamorphic mineral assemblages suggest that the area was heated up to $300^{\circ} \mathrm{C}$. This secondary ChRM is carried by secondary magnetite, which was produced during this event. 
Table 1. Paleomagnetic data of volcanic and intrusive rocks. $N / n$ : total measured samples/number of samples used for statistics. $D g$ and $I g$ are declination and inclination in geographic coordinates, while $D s$ and $I s$ are in stratigraphic coordinates. $k=$ estimate of precision parameter, $\alpha-95=$ semi angle of the circle of $95 \%$ confidence about the mean direction in the case of geographic coordinates.

\begin{tabular}{|c|c|c|c|c|c|c|c|c|c|}
\hline Site & $N / n$ & $D g^{\circ}$ & $I g^{\circ}$ & $D s^{\circ}$ & $I s^{\circ}$ & $k$ & $\alpha-95$ & $\begin{array}{l}\text { Strike/Dip* } \\
\text { (degrees) }\end{array}$ & $\begin{array}{l}\text { Sampling position } \\
\text { Lat./Long. }\end{array}$ \\
\hline \multicolumn{10}{|c|}{ Shamran Volcanics (ChRM) } \\
\hline SH1 & $6 / 6$ & 335.2 & 47.9 & 200.7 & 37.5 & 243.8 & 4.3 & $90 / 90$ & $36^{\circ} 14.863^{\prime} \mathrm{N} / 73^{\circ} 21.518^{\prime} \mathrm{E}$ \\
\hline $\mathrm{SH} 3$ & $6 / 6$ & 356.3 & 53.4 & 348.4 & 62.1 & 264.2 & 4.1 & $112 / 10$ & $36^{\circ} 11.918^{\prime} \mathrm{N} / 73^{\circ} 14.543^{\prime} \mathrm{E}$ \\
\hline SH5 & $6 / 6$ & 135.6 & -32.4 & 90.5 & -18.5 & 18.5 & 25.3 & $121 / 78$ & $36^{\circ} 11.127^{\prime} \mathrm{N} / 73^{\circ} 11.803^{\prime} \mathrm{E}$ \\
\hline SH9 & $6 / 6$ & 339.1 & 39.3 & 203.5 & 46.3 & 427.2 & 3.2 & $90 / 90$ & $36^{\circ} 14.851^{\prime} \mathrm{N} / 73^{\circ} 21.543^{\prime} \mathrm{E}$ \\
\hline SH11 & $6 / 6$ & 341.8 & 42.2 & 345.0 & -25.0 & 231.1 & 4.4 & $270 / 70$ & $36^{\circ} 11.857^{\prime} \mathrm{N} / 73^{\circ} 14.419^{\prime} \mathrm{E}$ \\
\hline SH14 & $6 / 6$ & 340.9 & 51.5 & 207.0 & 36.9 & 142.9 & 5.7 & $97 / 87$ & $36^{\circ} 11.801^{\prime} \mathrm{N} / 73^{\circ} 14.674^{\prime} \mathrm{E}$ \\
\hline SH6 $6^{* *}$ & $6 / 5$ & 21.5 & 13.6 & 7.3 & 4.9 & 18.5 & 18.3 & $200 / 75$ & $36^{\circ} 10.590^{\prime} \mathrm{N} / 73^{\circ} 10.941^{\prime} \mathrm{E}$ \\
\hline \multicolumn{10}{|c|}{ Western Volcanics (ChRM) } \\
\hline IS1 & $6 / 6$ & 8.2 & 44.6 & 8.6 & -37.3 & 134.0 & 5.8 & $282 / 82$ & $36^{\circ} 14.458^{\prime} \mathrm{N} / 73^{\circ} 44.307^{\prime} \mathrm{E}$ \\
\hline \multicolumn{10}{|c|}{ Yasin Gp. Upper Volcanics } \\
\hline YS2 & $6 / 6$ & ChRM col & uld not be i & isolated & & & & & $36^{\circ} 23.852^{\prime} \mathrm{N} / 73^{\circ} 16.869^{\prime} \mathrm{E}$ \\
\hline \multirow[t]{3}{*}{ Mean** $^{* *}$} & \multirow[t]{3}{*}{7 sites } & & \multicolumn{3}{|c|}{ Geographic Coordinates } & \multicolumn{3}{|c|}{ Stratigraphic Coordinates } & \\
\hline & & & \multicolumn{3}{|c|}{$\mathrm{Dec}=341.6^{\circ} \quad \mathrm{Inc}=45.6^{\circ}$} & $\operatorname{Dec}=27$ & $73.1^{\circ}$ & $\mathrm{Inc}=50.0^{\circ}$ & \\
\hline & & & \multicolumn{3}{|c|}{$k=33.5 \quad \alpha-95=10.6$} & $k=1.6$ & \multicolumn{2}{|c|}{$\alpha-95=72.9$} & \\
\hline \multicolumn{10}{|c|}{ Intrusives (ChRM) } \\
\hline SH13 & $6 / 6$ & 162.1 & -26.7 & 49.7 & -56.4 & 207.4 & 5.0 & $97 / 87$ & $36^{\circ} 11.762^{\prime} \mathrm{N} / 73^{\circ} 14.677^{\prime} \mathrm{E}$ \\
\hline SH4 & $6 / 6$ & 338.0 & 42.2 & 330.4 & 48.9 & 228.9 & 4.4 & $112 / 10$ & $36^{\circ} 14.480^{\prime} \mathrm{N} / 73^{\circ} 19.956^{\prime} \mathrm{E}$ \\
\hline SH9G & $6 / 6$ & 5.6 & 42.8 & 174.0 & 46.9 & 44.0 & 10.6 & $90 / 90$ & $36^{\circ} 14.851^{\prime} \mathrm{N} / 73^{\circ} 21.543^{\prime} \mathrm{E}$ \\
\hline SH10 & $5 / 5$ & 120.6 & -39.2 & 119.0 & 35.0 & 45.6 & 11.5 & $200 / 75$ & $36^{\circ} 09.820^{\prime} \mathrm{N} / 73^{\circ} 09.723^{\prime} \mathrm{E}$ \\
\hline YS1 & $4 / 4$ & 175.0 & -37.5 & 176.7 & -7.6 & 39.4 & 14.8 & $270 / 30$ & $36^{\circ} 14.540^{\prime} \mathrm{N} / 73^{\circ} 25.201^{\prime} \mathrm{E}$ \\
\hline SH7 & $6 / 6$ & ChRM col & uld not be $\mathrm{i}$ & isolated & & & & & $36^{\circ} 09.801^{\prime} \mathrm{N} / 73^{\circ} 09.501^{\prime} \mathrm{E}$ \\
\hline SH16 & $6 / 6$ & ChRM col & uld not be i & isolated & & & & & $36^{\circ} 14.836^{\prime} \mathrm{N} / 73^{\circ} 41.361^{\prime} \mathrm{E}$ \\
\hline \multirow[t]{3}{*}{ Mean $^{* * *}$} & \multirow[t]{3}{*}{5 sites } & & \multicolumn{3}{|c|}{ Geographic Coordinates } & \multicolumn{3}{|c|}{ Stratigraphic Coordinates } & \\
\hline & & & \multicolumn{3}{|c|}{$\operatorname{Dec}=340.5^{\circ} \quad$ Inc $=39.8^{\circ}$} & \multirow{2}{*}{\multicolumn{3}{|c|}{$\begin{array}{l}\text { Dec }=305^{\circ} \quad \text { Inc }=39 . \\
k=2.2 \quad \alpha-95=69.7\end{array}$}} & \\
\hline & & & $k=16.0$ & $\alpha-95=$ & 19.7 & & & & \\
\hline \multicolumn{10}{|c|}{ Total Mean (Volcanics + Intrusives) } \\
\hline & & \multicolumn{4}{|c|}{ Geographic Coordinates } & & & & \\
\hline 12 sites & & $\begin{array}{l}\operatorname{Dec}=34 \\
(k=24.8\end{array}$ & $\begin{array}{l}1.0^{\circ} \quad \text { Inc }= \\
\alpha-95=\end{array}$ & $\begin{array}{l}=43.2^{\circ} \\
8.9)\end{array}$ & & & & & \\
\hline South Pol & osition I & lat. $70.4^{\circ} \mathrm{S}$ & Plong. 1 & $34.6^{\circ} \mathrm{E}$ & $d p=6.9$ & $d m=11.1$ & & & \\
\hline
\end{tabular}

Knowledge of the timing of acquisition of secondary remanent magnetizations is important for interpretations of paleomagnetic data. In the absence of any direct radiometric age control for these secondary remanent magnetizations, they can be dated only indirectly through comparison of their paleolatitudes with the paleolatitudinal control on India's northward movement. Klootwijk et al. (1991) investigated the paleolatitude history of India's northward motion during last $80 \mathrm{My}$. The calculated paleomagnetic pole for combined mean of the post-tilt ChRM directions of volcanics and intrusives $\left(70.4^{\circ} \mathrm{S}, 134.6^{\circ} \mathrm{E} ; d p=6.9, d m=11.1\right)$ lies with in swath defined by secondary poles of Early to Late Tertiary age in northwestern Himalaya (Table 3; Fig. 9). The simple comparison of paleolatitudes calculated from Indian APWP for the studied area to that of the post-tilt ChRMs of the present study would be inappropriate, if north-south crustal shortening of $470 \mathrm{~km}$ (about $4^{\circ}$ ) within Indian continent is ignored (Coward et al., 1987). Assuming that all 


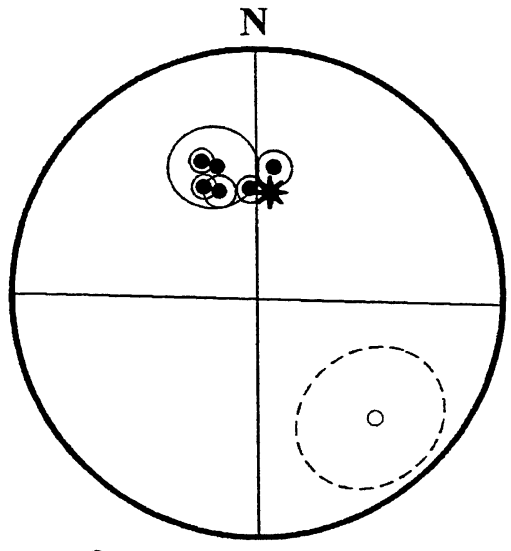

a

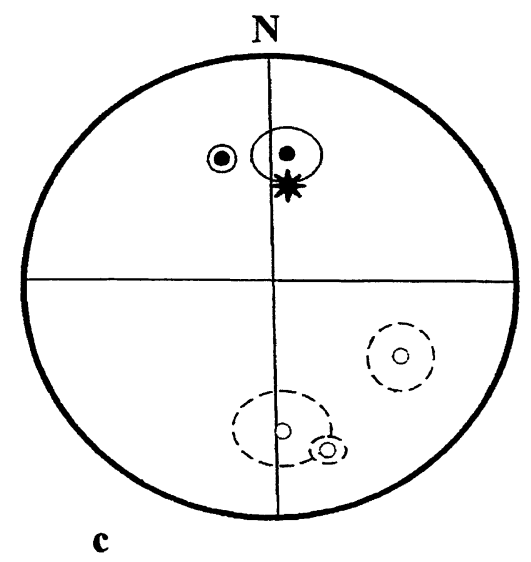

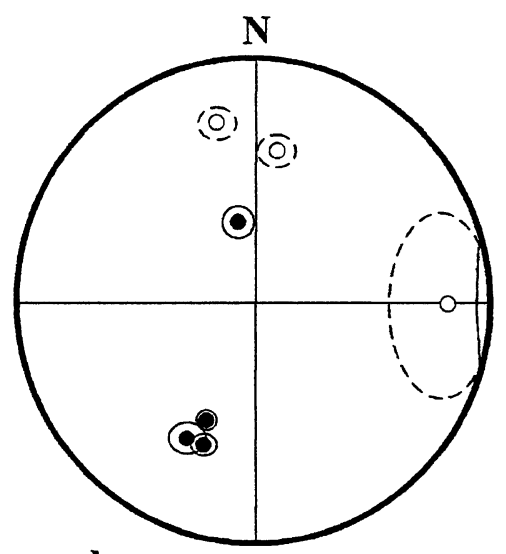

b

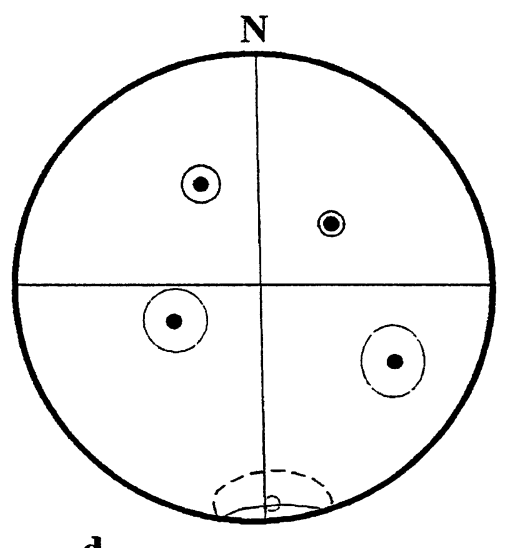

d

Fig. 8. Equal area projection of mean directions of ChRMs in case of a) volcanics in geographic coordinates b) volcanics in stratigraphic coordinates c) Intrusives in geographic coordinates d) intrusives in stratigraphic coordinates. The mark of star represents the present geomagnetic field direction for the area.

Table 2. South pole position for Indian plate from DSDP/ODP data in the interval 65-20 Ma (Klootwijk et al., 1991).

\begin{tabular}{ccc}
\hline Age & Longitude $^{\circ} \mathrm{E}$ & Latitude $^{\circ} \mathrm{S}$ \\
\hline $20 \mathrm{Ma}$ & 119.87 & 78.51 \\
$25 \mathrm{Ma}$ & 122.63 & 75.67 \\
$30 \mathrm{Ma}$ & 125.80 & 72.52 \\
$35 \mathrm{Ma}$ & 129.19 & 68.97 \\
$40 \mathrm{Ma}$ & 127.38 & 66.82 \\
$45 \mathrm{Ma}$ & 124.53 & 65.07 \\
$50 \mathrm{Ma}$ & 122.04 & 63.23 \\
$55 \mathrm{Ma}$ & 119.79 & 61.39 \\
$60 \mathrm{Ma}$ & 112.03 & 53.97 \\
$65 \mathrm{Ma}$ & 110.44 & 44.85 \\
\hline
\end{tabular}

shortening is occurred after the acquisition of ChRMs, then error will be of the order of 4 degrees. The present latitude of the area is $36^{\circ} \mathrm{N}$, if there would have been no crustal shortening ( of $4^{\circ}$ ); the position of the present study area must be $39^{\circ} \mathrm{N}$. Therefore in order to accommodate this shortening, paleolatitudes from APWP were calculated for $39^{\circ} \mathrm{N}$ instead of $36^{\circ} \mathrm{N}$ (Table 4). The mean paleolatitude of $25^{\circ} \mathrm{N}$ with an $\alpha-95$ of $8.9^{\circ}$ results in latitudinal range from $19^{\circ} \mathrm{N}$ to $33^{\circ} \mathrm{N}$. This error leads to large age uncertainties (50 to close to the present), when compared with Indian APWP (Table 4). However, there are some arguments that the acquisition of these ChRMs is not younger than $35 \mathrm{Ma}$.

1) ChRMs cannot be recent viscous magnetizations because the magnetizations have both polarity directions (Table 1; Fig. 8).

2) We interpret that secondary magnetite grains carry these secondary magnetizations. These secondary magnetite grains were formed during a metamorphic event, which metamorphosed some rocks of the area up to $300^{\circ} \mathrm{C}$ (lower greenschist facies). ${ }^{40} \mathrm{Ar} /{ }^{39} \mathrm{Ar}$ and $\mathrm{K}-\mathrm{Ar}$ ages of hornblendes and biotites of the rocks of the area can be used to place some constraints on the thermal history. Hornblende and biotite ages of a rock record the cooling ages through closure temperatures of $500^{\circ} \mathrm{C}$ and $300^{\circ} \mathrm{C}$ respectively (Zeitler, 1985). The plutonic rocks around Gilgit have biotite cooling ages through $300^{\circ} \mathrm{C}$ at about $45-35 \mathrm{Ma}$ and the plutons to the west of Gilgit (in our study area) have slightly older regional cooling ages (Treloar et al., 1989). The youngest biotite ages in the study area are $40 \pm 2 \mathrm{Ma}$ of Gupis pluton, $44 \pm 2 \mathrm{Ma}$ of Pingal pluton, $43 \pm 2 \mathrm{Ma}$ of Gakuch pluton (immediate east of the study area) and $38 \pm 2$ Ma of basic volcanics (western volcanics) (Treloar et al., 1989). Hence all these biotite ages indicate that the area was cooled down below $300^{\circ} \mathrm{C}$ 
Table 3. South pole positions of Early to Late Tertiary secondary magnetization components in NW Himalaya.

\begin{tabular}{|c|c|c|c|c|c|}
\hline Area/Rock unit & Pole Longitude ${ }^{\circ} \mathrm{E}$ & Pole Latitude ${ }^{\circ} \mathrm{S}$ & $d p$ & $d m$ & Reference \\
\hline Krol belt & 19.5 & 59.5 & 5.6 & 10.6 & Klootwijk (1984) \\
\hline Krol belt & 14.0 & 73 & 4.9 & 8.9 & Klootwijk (1984) \\
\hline Sulaiman Range/Mughal Kot Fm. & 29.0 & 57.5 & 2 & 4 & Klootwijk (1984) \\
\hline Sulaiman Range/Fort Munro Fm. & 11.0 & 60.5 & 3 & 6 & Klootwijk (1984) \\
\hline Centeral and Eastern Kashmir (34.5N, 74.3E) & 31 & 72.8 & 4.9 & 8.3 & Klootwijk (1984) \\
\hline Central and Eastern Kashmir (34.5N, 74.3E) & 13.3 & 64.0 & 5.0 & 8.1 & Klootwijk (1984) \\
\hline Central and Eastern Kashmir (34.5N, 74.3E) & 17.4 & 58.3 & 5.3 & 9.8 & Klootwijk (1984) \\
\hline Ladakh/Intrusives & 69.5 & 62.5 & 2 & 4 & Klootwijk et al. (1979) \\
\hline Ladakh/Dras Flyschoids & 52.0 & 53.5 & 2.5 & 5 & Klootwijk (1984) \\
\hline Ladakh/Dras Flyschoids & 91.5 & 55.5 & 2 & 4.5 & Klootwijk (1984) \\
\hline Ladakh/Dras Flyschoids & 38 & 48.5 & 3.5 & 6.5 & Klootwijk (1984) \\
\hline Ladakh/Dras Flyschoids & 81.5 & 57 & 2.5 & 5.5 & Klootwijk (1984) \\
\hline Ladakh/Indus Molasse & 139.5 & 40.5 & 8.5 & 16.5 & Klootwijk (1984) \\
\hline Ladakh/Indus Molasse & 145.5 & 30.5 & 12 & 24 & Klootwijk (1984) \\
\hline Ladakh/Indus Molasse & 76.5 & 58 & 5 & 10 & Klootwijk (1984) \\
\hline Ladakh/Indus Molasse & 94 & 58 & 4.5 & 9 & Klootwijk (1984) \\
\hline Baluchistan/Brewery Lst. & 141 & 54 & 2 & 3.5 & Klootwijk (1984) \\
\hline Baluchistan/Goru Fm. & 147.5 & 52.5 & 5 & 9 & Klootwijk (1984) \\
\hline Baluchistan/Alozai Fm. & 135.0 & 55.0 & 4.5 & 8.5 & Klootwijk (1984) \\
\hline Zanskar Range/Tethyan sediments & 144.3 & 66.0 & 4.2 & 7.1 & Appel et al. (1995) \\
\hline Kohistan arc/Shamran Volcanics and intrusives & 134.6 & 70.4 & 6.9 & 11.1 & This study \\
\hline
\end{tabular}

Table 4. Paleolatitudes obtained from pole positions of Indian APWP (Klootwijk et al., 1991) at site $39^{\circ} \mathrm{N}, 73^{\circ} \mathrm{E}$.

\begin{tabular}{cc}
\hline Age $(\mathrm{Ma})$ & Paleolatitude $\left({ }^{\circ} \mathrm{N}\right)$ \\
\hline 20 & 30.7 \\
25 & 29.0 \\
30 & 27.3 \\
35 & 25.6 \\
40 & 23.6 \\
45 & 21.5 \\
50 & 19.4 \\
55 & 17.3 \\
60 & 8.8 \\
\hline
\end{tabular}

before $35 \mathrm{Ma}$. Therefore the greenschist related secondary magnetite couldn't be formed after $35 \mathrm{Ma}$.

On the basis of the thermal history and comparison of the mean paleolatitude (within error limits) with the Indian APWP, a range of ages from 50 to $35 \mathrm{Ma}$ can be assigned to the secondary remanent magnetizations.

\subsection{Mechanism of remagnetization}

Secondary precipitation and growth of magnetite can produce thermochemical remanent magnetization (TCRM) during alteration of primary igneous phases. Optical study also indicates the presence of primary magnetite in the volcanics and intrusives. The possibility of thermally acquired sec- ondary remanent magnetization by the primary magnetite is ruled out, because no high temperature metamorphic mineral assemblages (of the range of magnetite Curie temperature) have been observed. The other type of remagnetization is thermoviscous remanent magnetization (TVRM), which is acquired at prolonged, elevated temperatures. The elevated temperature conditions did not last long in the area, because area was cool below $300^{\circ} \mathrm{C}$ before $35 \mathrm{Ma}$. According to Pullaiah et al. (1975) curves there is no possibility of complete remagnetization of magnetite grains (laboratory unblocking temperature $=570-580^{\circ} \mathrm{C}$ ) in the form of TVRM, even if low grade greenschist temperatures (300$350^{\circ} \mathrm{C}$ ) last since the time (about $60 \mathrm{Ma}$ ) of formation of volcanics and intrusives to $35 \mathrm{Ma}$. The insignificant contribution of the primary magnetite grains to ChRM, may be because of large (MD) primary magnetite grains, which do not carry a stable remanence. Only secondary magnetizations were also encountered in Aruba granites, which have both primary and secondary magnetite grains (Van der Voo, 1993, p. 62). There it has been interpreted that primary grains posses unstable remanence because of large size.

No younger intrusive activity has been reported in the area, which may be responsible for the remagnetization event. Now question arises, what is the cause of this widespread remagnetization in the area? It should be remembered that plutons could retain chemically active magmatic residual fluids long after the original plutonic activity. These fluids have water and other incompatible elements, which are unable to crystallize at prevailing temperature and exsolves from the 


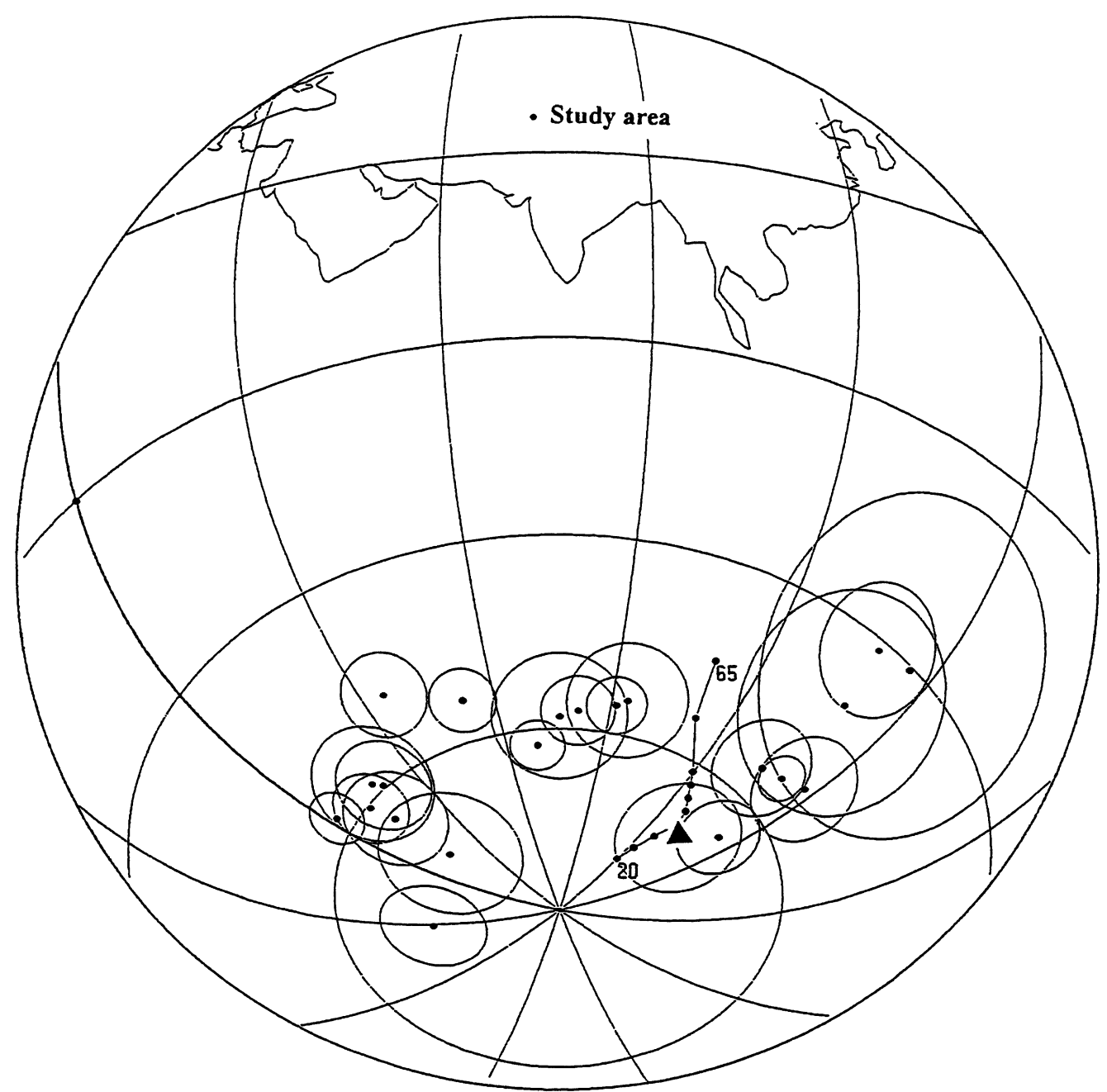

Fig. 9. Comparison of pole obtained from mean direction of ChRM of volcanics and intrusives with Indian APWP and other Early to Late Tertiary secondary remanences of NW Himalaya. Black triangle represents the pole position obtained from present study. Black dots connected by line represent Indian APWP from $65 \mathrm{Ma}$ to $20 \mathrm{Ma}$ at the interval of $5 \mathrm{Ma}$. Black dots encircled by $95 \%$ confidence limit are the other secondary poles from Early to Late Tertiary age.

crystallizing rock (Middlemost, 1997, p. 204).The remagnetization may be due to release of hydrothermal fluids of plutons, during the uplift of the area. The K-Ar biotite ages of about $40 \mathrm{Ma}$ from these rocks suggest that the part of the area was still at $300^{\circ} \mathrm{C}$ at that time. Hence the possibility of circulation of hot hydrothermal fluids related with plutons at about 50-35 Ma cannot be ignored. The circulation of these hydrothermal fluids produced secondary magnetite and greenschist mineral assemblages.

\section{Conclusions}

The dominant magnetic carrier is magnetite in the studied rocks. Both in volcanics as well as plutons secondary magnetite is observed and all rocks have been effected by low-grade metamorphism. The ChRMs of both volcanics as well as plutons are of secondary nature, and are interpreted to have been acquired during low-grade metamorphism and is thermo chemical remanent magnetization (TCRM). The ChRMs were acquired at $25 \pm 6^{\circ} \mathrm{N}$. Comparison of the mean paleolatitude with the present latitude suggests about $10^{\circ}$ northward movement of the area after the acquisition of ChRMs. According to the thermal history of the area and comparison of the calculated paleolatitude, within the confidence ranges, with the Indian APWP, the age of remagnetization can be bracketed between 50 and $35 \mathrm{Ma}$.

Acknowledgments. We are grateful to Dr. Mitsuo Yoshida for reviewing an early draft of the manuscript. Drs. Hiroshi Amitsuka and Keitaro Kuwahara of the Division of Physics, Hokkaido University are acknowledged for their help in low temperature measurements. We wish to thank Mr. Toshiaki Kuwajima and Mr. Hidehiko Nomura for helping in preparation of thin sections. Authors are indebted to Mr. M. Sakawat, Director, Geoscience Laboratory, Geological Survey of Pakistan, for providing us field equipment during the fieldwork in northern Pakistan. Comments and suggestions of two anonymous reviewers and editor Hidefumi Tanaka helped a lot to improve the manuscript.

\section{References}

Ade-Hall, J. M., H. C. Palmer, and T. P. Hubbard, The magnetic and opaque petrological response of basalts to regional hydrothermal alteration, Geophys. J. R. astr. Soc., 24, 137-174, 1971.

Ahmad, M. N., M. Yoshida, and Y. Fujiwara, Paleomagnetic study of Utror Volcanic Formation: Remagnetizations and postfolding rotations in Utror area, Kohistan arc, northern Pakistan, Earth Planets Space, 52, 425-436, 2000 
Appel, E., A. Patzelt, and C. Chouker, Secondary paleoremanences of Tethyan sediments from Zanskar Range (NW Himalaya), Geophys. $J$. Int., 122, 227-242, 1995

Coward, M. P., R. W. H. Butler, M. A. Khan, and R. J. Knipe, The tectonic history of Kohistan and its implications for Himalayan structure, J. Geol. Soc. London, 144, 377-391, 1987.

Dunlop, D. J. and O. Ozdemir, Rock magnetism: fundamentals and frontiers, 573 pp., Cambridge University Press, New York, 1997.

Fisher, G. M., Dispersion on a sphere, Proc. R. Soc. London, A217, 295-305, 1953.

Khan, M. A., R. J. Stern, R. F. Gribble, and B. F. Windley, Geochemical and isotopic constraints on subduction polarity, magma sources, and palaegeography of Kohistan intra-oceanic arc, northern Pakistan Himalaya, $J$. Geol. Soc. London, 154, 935-946, 1999.

Kirschvink, J. L., The least squares line and plane and the analysis of the paleomagnetic data, Geophys. J. R. astr. Soc., 62, 699-718, 1980.

Klootwijk, C. T., A review of Indian Phanerozoic Paleomagnetism: Implications for the India-Asia collision, Tectonophys., 105, 331-353, 1984.

Klootwijk, C. T. and P. J. Conaghan, The extend of greater India, 1. Preliminary Paleomagnetic data from the Upper Devonian of the Eastern Hindukush, Chitral (Pakistan), Earth Planet. Sci. Lett., 42, 167-182, 1979.

Klootwijk, C. T., M. L. Sharma, J. Gergan, B. Tirkey, S. K. Shah, and V. Agarwal, The extend of Creater India, II. Paleomagnetic data from the Ladakh intrusives at Kargil, Northwestern Himalayas, Earth Planet. Sci. Lett., 44, 47-64, 1979.

Klootwijk, C. T., J. S. Gee, J. W. Percie, and G. M. Smith, Constraints on India-Asia Convergence: Paleomagnetic Results from Ninetyeast Ridge, in Proceedings of the Ocean Drilling Program, edited by J. Weissel, J. Peirce, E. Taylor, and J. Alt, Scientific Results, 121, pp. 777-881, 1991.

Klootwijk, C. T., P. J. Conaghan, R. Nazirullah, and K. De Jong, A. Further paleomagnetic data from Chitral (Eastern Hindukush): evidence for an early India-Asia contact, Tectonophys., 237, 1-25, 1994.

Middlemost, E., Magmas, Rocks and Planetary Development a survey of magma/igneous rock systems, 299 pp., Longman Singapore Publishers (Pte) Ltd., 1997.

Muffler, L. J. and D. E. White, Active metamorphism of Upper Cenozoic sediments in the Salton Sea Geothermal field and Salton Sea trough, South-eastern Califorinia, Bull. Geol. Soc. Am., 80, 157-180, 1969.

Ozdemir, O. and D. J. Dunlop, Low-temperature properties of a single crystal of magnetite oriented along principal magnetic axes, Earth Planet. Sci. Lett., 165, 229-239, 1999.

Ozdemir, O., D. J. Dunlop, and B. M. Moskowitz, The effect of oxidation on the Verwey Transition in Magnetite, Geophys. Res. Lett., 20, 1671-1674, 1993.

Petterson, M. G. and B. F. Windley, Rb-Sr dating of the Kohistan arcbatholith in the Trans Himalaya of north Pakistan, and tectonic implications, Earth Planet. Sci. Lett., 74, 45-57, 1985.

Pudsey, C. J., M. P. Coward, I. W. Luff, R. M. Shackelton, B. F. Windley, and M. Q. Jan, Collision zone between the Kohistan arc and Asian plate in NW Pakistan, Transaction of the Royal Society of Edinburg: Earth
Sciences, 76, 463-479, 1985.

Pullaiah, G., E. Iriving, K. L. Buchan, and D. C. Dunlop, Magnetization changes caused by burial and uplift, Earth Planet. Sci. Lett., 28, 133$143,1975$.

Searle, M. P., Geology and Tectonics of the Karakoram Mountains, 358 pp., John Wiley \& Sons, 1991.

Searle, M. P., M. A. Khan, J. E. Fraser, S. J. Gough, and M. Q. Jan, The tectonic evolution of Kohistan-Karakoram collision belt along Karakoram Highway transect, north Pakistan, Tectonics, 18, 929-949, 1999.

Sullivan, M. A., B. F. Windley, A. D. Saunders, J. R. Haynes, and D. C. Rex, A paleogeographic reconstruction of the Dir Group: evidence for magmatic arc migration within Kohistan, N. Pakistan, in Himalayan Tectonics, edited by P. J. Treloar and M. P. Searle, Geological Society London Special Publication 74, pp. 139-160, 1993.

Tahirkheli, R. A. K., M. Mattauer, F. Proust, and P. Tapponnier, The IndiaEurasia Suture Zone In Northern Pakistan: Synthesis and interpretation of recent data at plate scale, in Geodynamics of Pakistan, edited by A Farah and K. A DeJong, pp. 125-130, Geol. Surv. Pakistan, Quetta, 1979.

Treloar, P. J., D. C. Rex, P. G. Guise, M. P. Coward, M. P. Searle, B. F. Windeley, M. G. Petterson, M. Q. Jan, and I. F. Luff, K-Ar and Ar-Ar geochronology of Himalayan collision in NW Pakistan: constraints on the timing of suturing, deformation, metamorphism and uplift, Tectonics, 8, 881-909, 1989 .

Treloar, P. J., M. G. Petterson, M. Q. Jan, and M. A. Sullivan, A re-evaluation of the stratigraphy and evolution of the Kohistan arc sequence, Pakistan Himalaya: implications for magmatic and tectonic arc-building processes, J. Geol. Soc. London, 153, 681-693, 1996.

Twiss, R. J. and E. M. Moores, Structural Geology, 532 pp., W. H. Freeman and Company, New York, 1992.

Van der Voo, R., Paleomagnetism of the Atlantic, Tethys and lapetus oceans, 411 pp., Cambridge University Press, 1993.

Verwey, E. J. W., Electronic conductions of magnetite $\left(\mathrm{Fe}_{3} \mathrm{O}_{4}\right)$ and its transition point at low temperature, Nature, 144, 327-328, 1939.

Zaman, H. and M. Torii, Paleomagnetic study of Cretaceous red beds from eastern Hindukush ranges, northern Pakistan: Paleoreconstruction of the Kohistan-Karakoram composite unit before the India-Asia collision, Geophys. J. Int., 136, 719-738, 1999.

Zeitler, P. K., Cooling History of the NW Himalaya, Pakistan, Tectonics, 4, 127-151, 1985.

Zijderveld, J. D. A., A. C. Demagnetization of rocks: Analysis of results, in Methods in Paleomagnetism, edited by D. W. Collisions, K. M. Creer, and S. K. Runcorn, 609 pp., Elsevier, New York, 1967.

Zwing, A. and V. Bachtadse, Paleoposition of northern margin of Armorica in Late Devonian times: Paleomagnetic and rock magnetic results from Frankenstein Intrusive Complex (Mid-German Crystalline Rise), $J$. Geophys. Res., 105, 21445-21456, 2000.

M. N. Ahmad (e-mail: naseerrb@yahoo.com), Y. Fujiwara, and L. P. Paudel 